\title{
Free Cash Flow, Growth Opportunities, And Dividends: Does Cross-Listing Of Shares Matter?
}

\author{
Zijian Cheng, Xi'an Jiaotong University, China \\ Charles P. Cullinan, Bryant University, USA \\ Junrui Zhang, Xi'an Jiaotong University, China
}

\begin{abstract}
Corporate dividend policy should strike a balance between paying cash to shareholders when there are excess resources and retaining sufficient resources in the company to fund worthwhile projects. Using excess resources to pay dividends can help to avoid overinvestment by the company in inappropriate projects and/or other potential misuse of funds by managers for their own benefit. However, companies also need to avoid paying too much in dividends to ensure that adequate resources are available within the company to fund projects that could increase shareholder wealth (i.e., to avoid underinvestment). Cross-listing of company shares can improve governance and oversight, which may make the dividend policies of cross-listed companies more likely to avoid both over and underinvestment.
\end{abstract}

Using a sample of Chinese listed companies from 2003 to 2011, we find that cross-listed companies pay higher dividends than non-cross-listed companies when there are excess resources (measured by free cash flow), thereby reducing the potential for overinvestment/misuse of the resources by cross-listed companies. We also find that the dividends of cross-listed companies are lower than those of non-cross-listed companies when there are greater growth opportunities (measure by the market-to-book ratio), reflecting the reduced potential for underinvestment by cross-listed companies. We find more limited evidence that cross-listings may influence the relationship between dividend volatility and free cash flow and growth opportunities. Overall, our results suggest that companies cross-listing their shares have dividend policies that are more responsive than those of non-cross-listed companies to potential shareholder concerns about over and underinvestment.

Keywords: Dividend Policy; Cross-Listing; Free Cash Flow; Growth Opportunities

\section{INTRODUCTION}

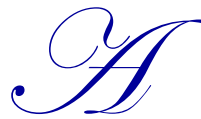

gency theory posits that corporate management may engage in behavior that is good for the managers themselves (i.e., the agent), but could be harmful for the shareholders (i.e., the principal) (Jensen \& Meckling, 1976). Examples of activities that may benefit managers but harm shareholders include managerial overcompensation and investments in projects that will enhance managerial compensation (Jensen, 1986) and prestige (Fairchild, 2010), but which may not benefit shareholders (i.e., overinvestment). One factor that has been viewed as exacerbating this overinvestment problem is high free cash flow. The cash flow may be misused by the managers for their own benefit (e.g., La Porta et al., 2000), and this potential misuse of resources is called the "free cash flow problem" (e.g., Fuller \& Blau, 2010). One way to reduce the free cash flow problem is to pay out more of the free cash flow as dividends (Fairchild, 2010), thereby sending the cash to the shareholders and reducing the chance that the managers may use the available resources inappropriately.

Growth opportunities have been found to influence dividend policy in the opposite direction from free cash flow (e.g., Mitton, 2004; Abor \& Bopkin, 2010). Companies with greater growth opportunities are more likely to 
pay lower (or no) dividends. The lower dividends permit companies to take advantage of the growth opportunities, as the resources not paid out as dividends (i.e., retained by the company) can be used to fund profitable projects which take advantage of the available growth opportunities. If lower dividend payments are not in place when growth opportunities are stronger, underinvestment in worthwhile projects may result (Guttman et al., 2010).

Shareholder-friendly dividend policies would therefore strike a balance between paying out dividends from free cash flow, while still retaining sufficient resources to fund worthwhile projects. Against such shareholderfriendly dividend policies is the potential for managers to act in their own self-interest in two possible ways. First, managers could pay lower or no dividends when the company has high free cash flow and use the retained resources for projects that would detract from shareholder value such as "unnecessary perks [and] unwarranted acquisitions and expansions" (Mukherjee \& Baker, 2009). Second, managers could pay out excessively high dividends when the resources used to fund the dividends could be better utilized by investing in projects that could enhance shareholder value.

One means of mitigating potential agency conflicts is through cross-listing of the company's shares. Companies cross-listing their shares subject themselves to greater scrutiny by foreign shareholders and foreign regulators, which can enhance the chance that managers of cross-listed companies will be more attuned to the needs of shareholders (Reese \& Weisbach, 2002). This potential for cross-listing to enhance managers' shareholder focus is termed "bonding" (Stulz, 1999; Coffee, 1999, 2002). Through enhanced bonding, cross-listings have also been found to enhance corporate governance (Charitou et al., 2007) and firm value (Doidge et al., 2004).

Companies focused on shareholder interests will tend to have higher dividends when there is more free cash flow in order to limit the ability of managers to make inappropriate investment decisions (Jensen, 1986; Fairchild, 2010), but have lower dividends when there are greater growth opportunities in order to retain resources to fund the growth opportunities (Abor \& Bopkin, 2010; Baker et al., 2012). One way of enhancing the chance that managers will better serve shareholder interests is through cross-listing of shares, which can enhance the scrutiny of the cross-listed company by both shareholders and regulatory bodies (Reese \& Wiesbach, 2002). Thus, we predict that the dividends of companies that cross-list their shares respond more (in a positive direction) to free cash flow than dividends of non-cross-listed companies. Similarly, we expect that the dividends of cross-listed firms respond more (in a negative direction) to growth opportunities than the dividends of non-cross-listed companies.

Using a sample of Chinese companies, we assess the potential effects of cross-listing on the relationship between free cash flow and dividend policy and between growth opportunities and dividend policy. We use Chinese companies for three main reasons. First, investor protection is viewed as weaker in China than that in other markets (Allen et al., 2005). When investor protection is weak in the home (i.e., Chinese) market, cross-listing of shares may be of greater benefit to shareholders (Zhou et al., 2011). Second, the Chinese stock market is fairly large, and crosslisting occurs with a reasonable frequency among Chinese companies, ${ }^{1}$ allowing for a reasonable sample size. Finally, Chinese companies are more likely to pay dividends than companies from other countries (Lam et al., 2012), allowing for more variation among dividends in the Chinese market than in some other markets where many companies pay no dividends at all (Fama \& French, 2001).

Based on our sample of Chinese companies over the period from 2003 to 2011, we find that Chinese crosslisted companies pay higher dividends than non-cross listed companies when they have greater free cash flow. We also find that Chinese cross-listed companies pay lower dividends than non-cross listed companies when they have greater growth opportunities. These results suggest that the enhanced governance associated with cross-listing may lead to dividend payments that enhance shareholder value by reducing the risk of both overinvestment (the free cash flow problem) and underinvestment (the growth opportunities idea).

We also examine the impact exerted by cross-listings on the relationship between free cash flow and dividend volatility. We find some limited evidence that dividends of cross-listed companies are more volatile than the dividends of non-cross-listed companies when free cash flow is higher. We also find limited evidence that the

\footnotetext{
${ }^{1}$ As presented in our results section below, 1,105 firm-years observations out of a total of 13,362 (i.e., 8.26\%) of Chinese-listed companies in our sample have cross-listed shares.
} 
dividends of cross-listed companies are more volatile than those of non-cross-listed companies when there are greater growth opportunities. The dividend payments may be more volatile because the cross-listed companies' dividends are more responsive to free cash flow and growth opportunities, and these free cash flows and growth opportunities could vary over time.

We contribute to the literature in three important ways. First, we assess whether the effects of the free cash flow and growth opportunities on dividend size may be influenced by share cross-listing. Second, we examine the relationships among free cash flow, growth opportunities, and cross listing on dividend volatility to capture an alternative measure of a company's dividend policy. Finally, we contribute to the body of literature on cross-listings by assessing whether the dividend policies of cross-listed companies may be more in accord with shareholders' interests in avoiding overinvestment and underinvestment.

\section{BACKGROUND LITERATURE AND HYPOTHESIS DEVELOPMENT}

\subsection{Free Cash Flow, Cross-Listings, and Dividend Policies}

Higher cash flows can benefit corporations by permitting them to use internally-generated capital to invest in projects with positive net present value that will enhance shareholder wealth. However, if available cash flows are greater than the amount needed to take advantage of shareholder-wealth-increasing projects, managers may invest in projects that will detract from firm value (Jensen, 1986; Noronha et al., 1995). By investing in projects unlikely to increase shareholder wealth (i.e., overinvesting), self-interested managers may act for their own benefit, ${ }^{2}$ rather than for the interests of the shareholders, thereby creating agency costs (La Porta et al., 2000; Mukherjee \& Baker, 2009). Richardson (2006) suggests that overinvestment is more likely to occur when companies have more free cash flow. Possible means of reducing the agency conflicts associated with excess free cash flow include more institutional shareholding (Karpavicius \& Yu, 2012), higher debt (Jensen, 1986), and stronger external auditing (Griffin et al., 2010).

Another mechanism to reduce the potential agency costs associated with excess cash flows (i.e., to avoid the free cash flow problem) is for the free cash flow to be distributed to shareholders as higher dividends. Jensen (1986, p. 323), however, notes the potential difficulty of convincing managers to pay out excess cash flow to shareholders as dividends:

"Conflicts of interest between shareholders and managers over payout policies are especially severe when the organization generates substantial free cash flow. The problem is how to motivate managers to disgorge the cash rather than investing it at below the cost of capital or wasting it on organization inefficiencies."

One means of encouraging managers to "disgorge the cash" (Jensen, 1986, p. 323) (i.e., pay the excess cash flow as dividends) is through enhanced corporate governance. Research has found that companies with higher quality corporate governance have higher dividend payout ratios (e.g., Adjaoud \& Ben-Amar, 2010; Jiraporn et al., 2011), which can reduce the agency costs associated with higher free cash flow.

Companies cross-listing their shares subject themselves to greater scrutiny from foreign investors and foreign regulatory bodies, and this scrutiny can result in better quality corporate governance (Charitou et al., 2007). Better quality governance can enhance the protection of shareholder rights through a stronger control consciousness and greater managerial focus on shareholder concerns. Supporting the stronger shareholder emphasis among crosslisted companies, Frésard and Salva (2010) find that cross-listings can enhance company value by making it more difficult for the managers to use corporate resources for their "private benefit" (Frésard \& Salva, 2010, p. 359).

Cross-listed companies may be more sensitive to shareholder concerns about potential overinvestment of excess free cash flow than would non-cross-listed companies. We therefore expect an interactive relationship among cross-listing status, free cash flow, and the size of dividend payments. Specifically, we expect that the dividends of

\footnotetext{
${ }^{2}$ Managers may invest in these sub-optimal projects to "empire build" (Fairchild, 2010, p. 395), and/or to obtain higher compensation as the company grows in size (Jensen 1986). 
cross-listed firms will be more responsive to free cash flow than the dividends of non-cross-listed companies. In other words, the relationship between free cash flow and dividends is expected to be stronger (more positive) for cross-listed companies than for non-cross-listed companies. This expectation is reflected in the following hypothesis:

Hypothesis 1a: The dividend payments of cross-listed companies respond more positively to free cash flow than the dividend payments of non-cross-listed companies.

In addition to the size of dividends, the volatility of dividends could reflect differences in dividend policy choices among companies (Lintner, 1956). However, the interactive effects of cross-listing and free cash flow on dividend volatility are more complex than their potential effects on dividend size. One possibility is that cross-listed firms may have less volatile dividend payments than non-cross-listed firms when free cash flow is higher. Gugler (2003) find that steady dividend policies can be used as a tool to constrain managers from turning free cash flow into private benefits in Austrian state-owned companies. Stable dividend streams will keep the cash flowing consistently to the shareholders and keep the resources out of the hands of the managers who may misuse them. Cross-listed companies are likely to be more sensitive to shareholder concerns, and therefore, may be more likely to use steady dividend payments as a tool to mitigate the potential agency problems associated with higher free cash flow.

However, another possibility arises when we factor in the prediction of Hypothesis H1a. Hypothesis H1a predicts that the dividend payments of cross-listed firms are more sensitive to free cash flow, and this sensitivity may cause greater dividend volatility among cross-listed companies because the free cash flows vary over time. Also, because cross-listed firms may make higher dividend payments when free cash flow is higher, it will be more difficult for cross-listed firms to keep stable dividend policies. Higher dividend payments are more difficult to sustain due to the lower availability of slack resources in the organization, especially during economic downturns. Therefore, the dividend payments of cross-listed companies may be more volatile relative to free cash flow than the dividend payments of non-cross-listed companies.

Finally, the two effects (i.e., either lower volatility due to the need to mitigate potential agency problem or higher volatility due to the difficulty of sustaining higher payments) could offset each other, resulting in no interactive relationship between cross-listing, free cash flow and dividend volatility. Because of these competing predictions, we propose a non-directional (i.e., null) hypothesis for the interactive relationship among free cash flow, cross-listings and dividend volatility as follows:

Hypothesis 1b: There is no interactive relationship between cross-listing, free cash flow and the companies' dividend volatility.

\subsection{Growth Opportunity, Cross-Listings, and Dividend Policies}

The free cash flow problem is based on concerns that managers may keep too much cash which they may invest in inappropriate projects. However, companies with greater growth opportunities could profitably invest the free cash flow in projects that take advantage of these growth opportunities. Therefore, companies with better growth opportunities may retain more resources to take advantage of the growth opportunities. Consistent with this notion, research indicates that companies with greater growth opportunities pay lower dividends (Abor \& Bopkin, 2010) or no dividends (Baker et al., 2012). Similarly, Fama and French (2001) find that the general decrease in dividend payments from 1978 to 1999 is associated with an increase in the number of companies with better growth opportunities.

La Porta et al. (2000) and Mitton (2004) both suggest that the negative relationship between dividends and growth opportunities will be stronger when corporate governance and shareholder protection (which can be enhanced by cross-listing) are better. Therefore, cross-listed companies with higher growth prospects may retain more cash (i.e., pay lower dividends) than non-cross-listed companies in order to invest in the available growth opportunities. Investors would accept these lower dividend payouts in exchange for the prospect of better returns when the investments pay off. We therefore expect an interactive relationship between cross-listing status, growth opportunities, and the size of dividend payments, as reflected in the following hypothesis: 
Hypothesis 2a: The dividend payments of cross-listed companies respond more negatively to growth opportunities than the dividend payments of non-cross-listed companies.

In addition to their potential effects on dividend size, growth opportunities could also influence the volatility of dividends. For example, Gugler (2003) and Leary and Michaely (2010) find that companies with lower growth opportunities have less volatile dividend payments. These findings may reflect the reduced competition between dividends and investments for resources when companies have fewer growth opportunities. This reduced competition for resources could help these firms make dividend payments on a more consistent basis. Consistent with Gugler (2003) and Leary and Michaely (2010), Mukherjee and Baker (2009) argue that it is more difficult for firms with better growth prospects to sustain dividends at a steady level since "a firm's investment needs . . might fluctuate from one year to the next."

Cross-listing is expected to enhance the shareholder focus of companies, so cross-listed companies (as predicted by H2a) may be more likely to retain resources to allow them to take advantage of growth opportunities that could benefit shareholders. However, these growth opportunities could vary across time. Therefore, we expect that cross-listed firms with better growth prospects may follow more volatile dividend policies because they are more likely to retain resources to take advantage of good projects and the availability of these projects can vary across time. This is the final hypothesis of our study and is stated as follows:

Hypothesis 2b: Dividends of companies with strong growth opportunities are more volatile for cross-listed companies than for non-cross-listed companies.

\section{DATA AND METHODOLOGY}

\subsection{Sample Selection}

We obtained data from the China Stock Market \& Accounting Research Database (CSMAR) on dividend size and volatility, companies' cross-listing status, free cash flow, growth opportunities and various control variables, such as the ownership structure, profitability, financial leverage, and size. We collect data for Chinese public firms in the CSMAR database for the period from 2003 to 2011. We exclude financial firms because their financial and accounting characteristics are different from those of firms from other industries. We also exclude companies listed on the Growth Enterprise Market (GEM) because the GEM was established in 2009, leaving insufficient data to measure the volatility of these companies' dividends. We also require five-year lag data to construct the dividend volatility measures (which for observations from the year 2003 requires data as early as 1999). These data restrictions yielded a sample of 13,362 firms-year observations, with 1,105 firm-year observations representing cross-listed companies, and 12,257 observations representing non-cross-listed companies.

\subsection{Main Variables and Models}

Table 1 displays the variables used in our models and their definitions. We employ three proxies for dividend size. The first proxy is a dummy variable $D P_{i, t}$ (dividend payment) which equals one if a firm makes dividend payments and zero otherwise. Two continuous variables are also used to measure dividend size: dividendto-sales ratio $\left(D S_{i, t}\right)$ and dividend-to-equity ratio $\left(D E_{i, t}\right)$. These proxies for dividend policies are widely used in many studies (e.g., La Porta et al., 2000). For the dummy dependent variable $\left(D P_{i, t}\right)$, we employ a pooled Logit analysis. For the continuous dependent variables $\left(D S_{i, t}\right.$ and $\left.D E_{i, t}\right)$, a large number of observations have the value of 0 (i.e., the variables are left censored). For these continuous dependent variables, we use pooled Tobit models, which are more appropriate than OLS regression when many observations have a zero value.

In order to measure dividend volatility, the standard deviations of $D S_{i, t}$ and $D E_{i, t}$ (by company) over a rolling five year period $\left(S t d D S_{i, t}\right.$ and $\left.S t d D E_{i, t}\right)$ are calculated. For instance, dividend volatility in 2003 is computed based on data from 1999 to 2003 . A five-year period is chosen because it is considered long enough for a company to establish a dividend policy (Gwilym et al., 2000). In China, many listed firms pay no dividend to shareholders during the five-year periods. These firms, together with the firms that make unchanged dividend payments, have the most stable dividend policy. Therefore, (similar to the dividend size measure of $D S_{i, t}$ and $D E_{i, t}$ ) the dividend volatility variables $\left(\operatorname{StdDS} S_{i, t}\right.$ and $\left.\operatorname{StdDE} E_{i, t}\right)$ are also left censored at 0 . We first conduct an analysis of dividend 
volatility using pooled Tobit model on the full sample. We then exclude firms that pay no dividends to shareholders in the rolling five-year period to create a reduced sample. This step is necessary to distinguish companies that do not pay dividends at all from companies that pay very stable dividends. We use pooled OLS model on this reduced sample to examine dividend volatility among these dividend-paying companies.

We create a dummy variable $\left(C L_{i, t}\right)$ to measure cross-listing status of the company; this variable equals one if a company cross-lists their shares and zero otherwise. We use the size of free cash flow divided by the book value of total assets to measure companies' free cash flows $\left(F C F_{i, t}\right)$. The growth opportunity measure $\left(G O_{i, t}\right)$ we use is market-to-book ratio, which is also used in many other studies of dividend policies (e.g. Chae et al., 2009). The first step in our analysis is to examine whether the correlations between free cash flow and growth opportunities and dividend size and stability vary based on the company's cross-listing status.

To test Hypothesis $1 \mathrm{a}$ and $1 \mathrm{~b}$ (which posit an interactive relationship between cross-listing status and free cash flow) we use the interaction variable $C L^{*} F C F_{i, t}$ in our models of dividend size (to test $\mathrm{H} 1 \mathrm{a}$ ) and dividend volatility (to test $\mathrm{H} 1 \mathrm{~b})$. Hypotheses $2 \mathrm{a}$ and $2 \mathrm{~b}$ posit that cross-listing could interact with growth opportunities to influence dividend size and volatility. We include the interaction variable $C L_{i, t}{ }^{*} G O_{i, t}$ in our models of dividend size (testing H2a) and volatility (testing $\mathrm{H} 2 \mathrm{~b}$ ).

Table 1: Variable Definitions

\begin{tabular}{ll}
\hline Variables & \multicolumn{1}{c}{ Definitions } \\
\hline$D P_{i, t}$ & If a firm makes dividend payments then $D P_{i, t}=1$, otherwise $D P_{i, t}=0$. \\
$D S_{i, t}$ & Cash dividends as a percentage of sales. \\
$D E_{i, t}$ & Cash dividends as a percentage of book value of equity. \\
$S t d D S_{i, t}$ & Rolling standard deviation of $D S_{i, t}$ of previous five years. \\
$S t d D E_{i, t}$ & Rolling standard deviation of $D E_{i, t}$ of previous five years. \\
$C L_{i, t}$ & If a firm cross-lists its stocks in other markets, then $C L_{i, t}=1$, otherwise $C L_{i, t}=0$ \\
$F C F_{i, t}$ & $F C F_{i, t}=($ earnings + interest expense on debt + non-cash expense - the change in working capital from the \\
$G O_{i, t}$ & previous year to the current year - capital expenditure) / book value of total assets. \\
$S O E_{i, t}$ & Market to book ratio of equity \\
$S 10_{i, t}$ & If a firm is state-owned, then $S O E_{i, t}=1$, otherwise $S O E_{i, t}=0$ \\
$R O E_{i, t}$ & Percentage of shares held by top ten investors \\
$L e v_{i, t}$ & Earnings divided by book value of equity \\
$S i z e_{i, t}$ & Book value of liability divided by book value of assets \\
\hline
\end{tabular}

Our multivariate analysis includes control variables for other factors that could influence company's dividend policies. Consistent with Gugler and Yurtoglu (2003) and Lam et al. (2012), we control ownership concentration as a factor in dividend policy. We employ $S 10_{i, t}$, which reflects the percentage of shares held by the top ten investors as a proxy for the ownership concentration. We also control for state ownership because Chen et al. (2009) suggest that Chinese state-owned firms tend to pay higher dividends and because Gugler (2003) find that state-owned companies are more likely to smooth dividend payments. Therefore, we include a binary variable $\left(S O E_{i, t}\right)$ in our analysis to control for the potential effects of state ownership on dividend policy. $S O E_{i, t}$ equals one if the company's largest owner is a governmental (i.e., state) entity, and zero otherwise.

Finally, we also control for other firm-level characteristics in our regression analysis, including profitability, leverage, and firm size. We employ the return on equity ratio $\left(R O E_{i, t}\right)$ as the proxy for profitability. The financial leverage measure we use is debt/asset ratio $\left(\operatorname{Lev}_{i, t}\right)$, while the log of total assets is used to measure the firm size $\left(\right.$ Size $\left._{i, t}\right)$. Year dummies and industry dummies are also included in our multivariate analysis. We winsorize all variables except $C L_{i, t}, S O E_{i, t}, S 10_{i, t}$, and $\mathrm{Size}_{i, t}$ at $1 \%$ in each tail in order to reduce the effect of outliers.

\section{RESULTS}

\subsection{Correlation Analysis}

Panel A of Table 2 presents the Pearson correlation coefficients between free cash flow and the various measures of dividend policy, with the observations divided into cross-listed and non-cross-listed sub-samples. For 
the cross-listed companies, free cash flow and dividend payments $\left(D P_{i, t}, D S_{i, t}\right.$, and $\left.D E_{i, t}\right)$ are positively correlated, while free cash flow and dividend payments are negatively related in the non-cross-listed sub-sample. The differences in these correlations between the cross-listed and non-cross-listed sub-samples are statistically significant. These results are consistent with our expectation in H1a that the dividends of cross-listed companies respond more strongly to free cash flow. Regarding dividend volatility, free cash flow is positively related to dividend volatility $\left(\operatorname{StdDS} S_{i, t}\right.$, and $\left.S t d D E_{i, t}\right)$ in both the cross-listed and the non-cross-listed sub-samples. The correlations are significantly larger in the cross-listed sub-sample than in the non-cross-listed sub-sample. All of these free cash flow/dividend correlation results indicate that the dividend policies of cross-listed firms respond more strongly to free cash flow than do the dividends of non-cross-listed companies.

Table 2: A Comparison of Correlation Coefficients between Free Cash Flow, Growth Opportunities and Dividend Policies by Cross-Listing Status

\begin{tabular}{lccc}
\hline Panel A: Correlations with Free Cash Flow & & \\
& $\begin{array}{c}\text { Cross-Listed } \\
\text { Companies }\end{array}$ & $\begin{array}{c}\text { Non-Cross Listed } \\
\text { Companies }\end{array}$ & \multicolumn{2}{c}{ Test of Difference between Correlation } \\
\cline { 3 - 4 } Coefficients
\end{tabular}

Variable Definitions: See Table 1. In the reduced sample, we excluded companies that pay no dividends to shareholders over a continuous fiveyear period. The $\mathrm{p}$ values are one-tailed for the directional hypotheses. *, **, ***denote significance at the $10 \%, 5 \%$, and $1 \%$ levels, respectively.

Panel B of Table 2 presents the Pearson correlation coefficients between growth opportunities and dividend policies for the cross-listed and non-cross-listed sub-samples. Growth opportunities are negatively related to dividend size for both the cross-listed and non-cross-listed samples. As expected, however, the correlations between growth opportunities and dividend size are more negative in the cross-listed sub-sample than in the non-cross-listed sub-sample. The correlation results between growth opportunities and dividend volatility are mixed. When we include companies regardless of whether they pay dividends or not, we find significantly negative correlations between growth opportunities and dividend volatility. These correlations are (opposite to our expectation) more negative for the cross-listed sub-sample than for the non-cross-listed sub-sample, but this difference is only marginally significant. When we exclude companies that pay no dividends over a rolling five-year window (the reduced sample), we find mostly positive correlations between growth opportunities and dividend volatility. We also find that the correlations for dividend paying companies between growth opportunities and dividend volatility differ between the cross-listed and non-cross-listed sub-samples (with marginal significance for $\operatorname{StdDS}_{i, t}$ and significance at $\mathrm{p} \leq 0.01$ for $\left.S t d D E_{i, t}\right)$. Overall, the correlation results are consistent with our expectations that the dividend policies of cross-listed firms are more sensitive to growth opportunities than are those of non-cross-listed firms. 


\subsection{Regression Analyses}

\subsubsection{Free Cash Flow, Cross-Listing, and Dividends}

Table 3 presents the results examining the potential effects of free cash flow and cross-listing on dividend size and dividend volatility (Hypotheses $1 \mathrm{a}$ and $1 \mathrm{~b}$ ). The first three columns present the results of testing the potential interactive effects of free cash flow and cross-listings on dividend size. The coefficients on the $C L^{*} F C F_{i, t}$ variable are significantly positive (at the $1 \%$ level) for all of three measures of dividend size (i.e., $D P_{i, t}, D S_{i, t}$, and $D E_{i, t}$ ). These results are consistent with $\mathrm{H} 1 \mathrm{a}$, which posited that the dividends of cross-listed companies would respond more strongly to the companies' free cash flow than the dividends of non-cross-listed companies. The findings are also consistent with the notion that the enhanced shareholder protection of cross-listed companies could force managers to pay higher dividends to shareholders when free cash flow is higher, thus constraining mangers from overinvesting the company's resources in inappropriate projects.

Table 3: The Interactive Effects of Cross-Listings and Free Cash Flow on Dividend Size and Volatility

\begin{tabular}{|c|c|c|c|c|c|c|c|}
\hline & \multicolumn{3}{|c|}{$\begin{array}{r}\text { Dividend Size } \\
\end{array}$} & \multicolumn{4}{|c|}{ Dividend Volatility } \\
\hline & \multirow{2}{*}{$\begin{array}{c}\text { Logit Model } \\
\text { (1) } D P_{i, t}\end{array}$} & \multicolumn{2}{|c|}{$\begin{array}{c}\text { Tobit Model } \\
\end{array}$} & \multicolumn{2}{|c|}{ Tobit Model (full sample) } & \multicolumn{2}{|c|}{ OLS Model (reduced sample) } \\
\hline & & (2) $D S_{i, t}$ & (3) $D E_{i, t}$ & (4) $S t d D S_{i, t}$ & (5) $S t d D E_{i, t}$ & (6) $S t d D S_{i, t}$ & $(7) S t d D E_{i, t}$ \\
\hline$C L^{*} F C F_{i, t}$ & $\begin{array}{c}3.2816^{* * * *} \\
(4.7995)\end{array}$ & $\begin{array}{c}0.0882 * * * \\
(6.6503)\end{array}$ & $\begin{array}{c}0.0527 * * * \\
(5.7293)\end{array}$ & $\begin{array}{l}0.0111^{*} \\
(1.6824)\end{array}$ & $\begin{array}{c}0.0115^{* *} \\
(2.5491)\end{array}$ & $\begin{array}{c}0.0011 \\
(0.1538)\end{array}$ & $\begin{array}{c}0.0046 \\
(1.0092)\end{array}$ \\
\hline$C L_{i, t}$ & $\begin{array}{c}-0.9998 * * * \\
(-10.1854)\end{array}$ & $\begin{array}{c}-0.0196 * * * \\
(-9.8900)\end{array}$ & $\begin{array}{r}-0.0144 * * * \\
(-10.5317)\end{array}$ & $\begin{array}{l}-0.0150 * * * \\
(-15.7517)\end{array}$ & $\begin{array}{c}-0.0093 * * * \\
(-14.4088)\end{array}$ & $\begin{array}{c}-0.0070 * * * \\
(-7.2051)\end{array}$ & $\begin{array}{c}-0.0027 * * * \\
(-4.2987)\end{array}$ \\
\hline$F C F_{i, t}$ & $\begin{array}{c}-0.3039 * * * \\
(-2.6365)\end{array}$ & $\begin{array}{c}-0.0105^{* * * *} \\
(-5.1503)\end{array}$ & $\begin{array}{l}-0.0001 \\
(-0.0903)\end{array}$ & $\begin{array}{c}0.0142 * * * \\
(7.9816)\end{array}$ & $\begin{array}{c}0.0099 * * * \\
(8.0914)\end{array}$ & $\begin{array}{c}0.0071 * * * \\
(3.9920)\end{array}$ & $\begin{array}{c}0.0041 * * * \\
(3.5343)\end{array}$ \\
\hline$G \boldsymbol{O}_{i, t}$ & $\begin{array}{c}-0.1931 * * * \\
(-14.7014)\end{array}$ & $\begin{array}{c}-0.0025 * * * \\
(-9.5348)\end{array}$ & $\begin{array}{l}-0.0022 * * * \\
(-12.4087)\end{array}$ & $\begin{array}{c}-0.0002 * * \\
(-2.3801)\end{array}$ & $\begin{array}{c}0.0000 \\
(0.0790)\end{array}$ & $\begin{array}{c}0.0008 * * * \\
(6.6012)\end{array}$ & $\begin{array}{c}0.0010^{* * * *} \\
(13.2659)\end{array}$ \\
\hline$S O E_{i, t}$ & $\begin{array}{c}0.1817 * * * \\
(3.7270)\end{array}$ & $\begin{array}{c}0.0054 * * * \\
(5.2193)\end{array}$ & $\begin{array}{c}0.0039 * * * \\
(5.4713)\end{array}$ & $\begin{array}{c}0.0014 * * \\
(2.5696)\end{array}$ & $\begin{array}{c}0.0018 * * * \\
(4.8218)\end{array}$ & $\begin{array}{l}-0.0003 \\
(-0.5755)\end{array}$ & $\begin{array}{c}0.0012 * * * \\
(3.3504)\end{array}$ \\
\hline$S 10_{i, t}$ & $\begin{array}{c}0.0233 * * * \\
(14.3676)\end{array}$ & $\begin{array}{c}0.0006 * * * \\
(16.8977)\end{array}$ & $\begin{array}{c}0.0004 * * * \\
(18.4891)\end{array}$ & $\begin{array}{c}0.0002 * * * \\
(9.4658)\end{array}$ & $\begin{array}{c}0.0001 * * * \\
(12.1569)\end{array}$ & $\begin{array}{c}0.0001 * * * \\
(7.0540)\end{array}$ & $\begin{array}{c}0.0001 * * * \\
(9.5559)\end{array}$ \\
\hline $\boldsymbol{R O E}_{i, t}$ & $\begin{array}{c}13.3744 * * * \\
(33.4167)\end{array}$ & $\begin{array}{r}0.2618 * * * \\
(36.9657)\end{array}$ & $\begin{array}{r}0.2610 * * * \\
(51.8317)\end{array}$ & $\begin{array}{c}-0.0005 \\
(-0.3990)\end{array}$ & $\begin{array}{c}0.0077 * * * \\
(8.7114)\end{array}$ & $\begin{array}{c}-0.0046 * * * \\
(-3.2930)\end{array}$ & $\begin{array}{c}0.0082 * * * \\
(9.0273)\end{array}$ \\
\hline $\operatorname{Lev}_{i, t}$ & $\begin{array}{c}-3.8866 * * * \\
(-25.7603)\end{array}$ & $\begin{array}{r}-0.1357 * * * \\
(-45.7958)\end{array}$ & $\begin{array}{c}-0.0646 * * * \\
(-31.7647)\end{array}$ & $\begin{array}{r}-0.0466 * * * \\
(-30.3267)\end{array}$ & $\begin{array}{c}-0.0186 * * * \\
(-17.7349)\end{array}$ & $\begin{array}{c}-0.0368 * * * \\
(-24.3113)\end{array}$ & $\begin{array}{c}-0.0059 * * * \\
(-5.9897)\end{array}$ \\
\hline Size $_{i, t}$ & $\begin{array}{l}1.5159 * * * \\
(21.2628)\end{array}$ & $\begin{array}{c}0.0245 * * * \\
(19.0026)\end{array}$ & $\begin{array}{c}0.0154 * * * \\
(17.2526)\end{array}$ & $\begin{array}{c}0.0168 * * * \\
(25.1475)\end{array}$ & $\begin{array}{c}0.0126 * * * \\
(27.7323)\end{array}$ & $\begin{array}{c}0.0039 * * * \\
(5.9174)\end{array}$ & $\begin{array}{c}0.0025 * * * \\
(5.8392)\end{array}$ \\
\hline Constant & $\begin{array}{c}-12.9976 * * * \\
(-15.2822)\end{array}$ & $\begin{array}{c}-0.2139 * * * \\
(-13.3971)\end{array}$ & $\begin{array}{c}-0.1387 * * * \\
(-12.5385)\end{array}$ & $\begin{array}{r}-0.1378 * * * \\
(-10.7854)\end{array}$ & $\begin{array}{c}-0.1101 * * * \\
(-13.3951)\end{array}$ & $\begin{array}{c}-0.0059 \\
(-0.6002)\end{array}$ & $\begin{array}{l}-0.0065 \\
(-1.0001)\end{array}$ \\
\hline $\begin{array}{l}\text { Year } \\
\text { Industry }\end{array}$ & $\begin{array}{l}\text { Controlled } \\
\text { Controlled } \\
\end{array}$ & $\begin{array}{l}\text { Controlled } \\
\text { Controlled }\end{array}$ & $\begin{array}{l}\text { Controlled } \\
\text { Controlled }\end{array}$ & $\begin{array}{l}\text { Controlled } \\
\text { Controlled }\end{array}$ & $\begin{array}{l}\text { Controlled } \\
\text { Controlled }\end{array}$ & $\begin{array}{l}\text { Controlled } \\
\text { Controlled }\end{array}$ & $\begin{array}{l}\text { Controlled } \\
\text { Controlled }\end{array}$ \\
\hline$N$ & 13362 & 13362 & 13362 & 10334 & 10334 & 7811 & 7811 \\
\hline $\begin{array}{l}\text { Adj-R } \\
\text { Chi }^{2} \\
\text { Pseudo } R^{2} \\
\end{array}$ & $\begin{array}{c}5710.80 \\
0.3115 \\
\end{array}$ & 7001.14 & 7239.79 & 3703.15 & 2821.81 & 0.2781 & 0.1246 \\
\hline
\end{tabular}

Variable definitions: See Table 1. In the reduced sample, we excluded companies that pay no dividends to shareholders over a continuous fiveyear period. In parentheses, we report $\mathrm{z}$ statistics for Logit model and $\mathrm{t}$ statistics for Tobit and OLS models. *, **, ***denote significance at the $10 \%, 5 \%$, and $1 \%$ levels, respectively.

The last four columns of Table 3 present the results of testing the potential effects of cross-listing on the relationship between free cash flow and dividend volatility. In the Tobit model for the full sample, the coefficients of the interaction variable $\left(C L^{*} F C F_{i, t}\right)$ are positive and marginally significant at $0.10\left(\operatorname{StdDS} S_{i, t}\right)$ and significant $\left(S t d D E_{i, t}\right)$ at 0.05 . The results in the Tobit analysis imply that the dividend policies of cross-listed firms are more volatile when they have higher free cash flow. One possible explanation for these results is that, as the dividend payments of crosslisted firms are more sensitive to their free cash flows, managers of cross-listed firms could therefore increase (decrease) dividend payments when the company experiences increases (decreases) in their free cash flow and such dividend changes would increase the volatility of the companies' dividends. In the OLS regressions for the reduced sample (excluding companies that do not pay dividends), the interaction variable $\left(C L^{*} F C F_{i, t}\right)$ is not significant, 
suggesting that the free cash flow/dividend volatility relationship is not different between companies that do and do not cross-list their shares. The dividend volatility results overall provide limited evidence that the relationship between free cash flow and dividends volatility may be influenced by cross-listing status.

\subsubsection{Growth Opportunity, Cross-Listing, and Dividends}

Table 4 presents the results of testing whether cross-listing may influence the relationship between growth opportunities and dividend size/volatility. The first three columns present the models of dividend size (testing H2a). All of the coefficients on the interaction term $\left(C L^{*} G O_{i, t}\right)$ are negative and consistently significant. These results indicate that growth prospects are more negatively related to dividend payments for cross-listed companies than for non-cross-listed companies. These findings are consistent with H2a, which posits that cross-listed companies would be more likely than non-cross-listed companies to retain resources (rather than pay them out as dividends) when they have better growth opportunities.

Table 4: The Interactive Effects of Cross-Listings and Growth Opportunities on Dividend Size and Volatility

\begin{tabular}{|c|c|c|c|c|c|c|c|}
\hline & \multicolumn{3}{|c|}{$\begin{array}{r}\text { Dividend Size } \\
\end{array}$} & \multicolumn{4}{|c|}{ Dividend Volatility } \\
\hline & \multirow{2}{*}{$\begin{array}{c}\text { Logit Model } \\
\text { (1) } D P_{i, t}\end{array}$} & \multicolumn{2}{|c|}{ Tobit Model } & \multicolumn{2}{|c|}{ Tobit Model (full sample) } & \multicolumn{2}{|c|}{ OLS Model (reduced sample) } \\
\hline & & (2) $D S_{i, t}$ & (3) $D E_{i, t}$ & (4) $S t d D S_{i, t}$ & (5) $S t d D E_{i, t}$ & (6) $S t d D S_{i, t}$ & $(7) S t d D E_{i, t}$ \\
\hline$C L * G O_{i, t}$ & $\begin{array}{c}-0.1714 * * * \\
(-3.7637)\end{array}$ & $\begin{array}{c}-0.0021 * * \\
(-2.5676)\end{array}$ & $\begin{array}{c}-0.0015 * * * \\
(-2.7644)\end{array}$ & $\begin{array}{l}-0.0001 \\
(-0.3201)\end{array}$ & $\begin{array}{c}0.0000 \\
(0.1605)\end{array}$ & $\begin{array}{l}0.0007 * \\
(1.8088)\end{array}$ & $\begin{array}{c}0.0010 * * * \\
(3.8756)\end{array}$ \\
\hline$C L_{i, t}$ & $\begin{array}{c}-0.4508 * * * \\
(-3.2155)\end{array}$ & $\begin{array}{c}-0.0095 * * * \\
(-3.6147)\end{array}$ & $\begin{array}{c}-0.0078 * * * \\
(-4.3321)\end{array}$ & $\begin{array}{r}-0.0141 * * * \\
(-11.7189)\end{array}$ & $\begin{array}{l}-0.0088 * * * \\
(-10.9231)\end{array}$ & $\begin{array}{c}-0.0085 * * * \\
(-6.9465)\end{array}$ & $\begin{array}{c}-0.0046 * * * \\
(-5.7998)\end{array}$ \\
\hline$F C F_{i, t}$ & $\begin{array}{l}-0.2177^{*} \\
(-1.9351)\end{array}$ & $\begin{array}{c}-0.0086 * * * \\
(-4.2407)\end{array}$ & $\begin{array}{c}0.0010 \\
(0.7278)\end{array}$ & $\begin{array}{c}0.0150^{* * * *} \\
(8.6804)\end{array}$ & $\begin{array}{c}0.0107 * * * \\
(9.0463)\end{array}$ & $\begin{array}{c}0.0071 * * * \\
(4.1404)\end{array}$ & $\begin{array}{c}0.0044 * * * \\
(3.8780)\end{array}$ \\
\hline$G \boldsymbol{O}_{i, t}$ & $\begin{array}{c}-0.1873 * * * \\
(-14.1885)\end{array}$ & $\begin{array}{c}-0.0024 * * * \\
(-9.1753)\end{array}$ & $\begin{array}{l}-0.0021 * * * \\
(-12.0189)\end{array}$ & $\begin{array}{l}-0.0002 * * \\
(-2.2513)\end{array}$ & $\begin{array}{c}0.0000 \\
(0.0663)\end{array}$ & $\begin{array}{c}0.0007 * * * \\
(6.1968)\end{array}$ & $\begin{array}{c}0.0009 * * * \\
(12.4263)\end{array}$ \\
\hline$S O E_{i, t}$ & $\begin{array}{c}0.1792 * * * \\
(3.6781)\end{array}$ & $\begin{array}{c}0.0053 * * * \\
(5.0488)\end{array}$ & $\begin{array}{c}0.0038 * * * \\
(5.3352)\end{array}$ & $\begin{array}{c}0.0014 * * \\
(2.5273)\end{array}$ & $\begin{array}{c}0.0018 * * * \\
(4.7528)\end{array}$ & $\begin{array}{c}-0.0003 \\
(-0.6095)\end{array}$ & $\begin{array}{c}0.0011 * * * \\
(3.2583)\end{array}$ \\
\hline$S 10_{i, t}$ & $\begin{array}{c}0.0233 * * * \\
(14.3760)\end{array}$ & $\begin{array}{c}0.0006 * * * \\
(16.9511)\end{array}$ & $\begin{array}{c}0.0004 * * * \\
(18.5419)\end{array}$ & $\begin{array}{c}0.0002 * * * \\
(9.4653)\end{array}$ & $\begin{array}{c}0.0001 * * * \\
(12.1560)\end{array}$ & $\begin{array}{c}0.0001 * * * \\
(7.0179)\end{array}$ & $\begin{array}{c}0.0001 * * * \\
(9.4887)\end{array}$ \\
\hline$R O E_{i, t}$ & $\begin{array}{c}13.5073 * * * \\
(33.5330)\end{array}$ & $\begin{array}{c}0.2645 * * * \\
(37.1826)\end{array}$ & $\begin{array}{l}0.2627 * * * \\
(51.9713)\end{array}$ & $\begin{array}{c}-0.0005 \\
(-0.3904)\end{array}$ & $\begin{array}{c}0.0077 * * * \\
(8.6898)\end{array}$ & $\begin{array}{c}-0.0046 * * * \\
(-3.3417)\end{array}$ & $\begin{array}{c}0.0081 * * * \\
(8.9266)\end{array}$ \\
\hline$L e v_{i, t}$ & $\begin{array}{c}-3.8649 * * * \\
(-25.6111)\end{array}$ & $\begin{array}{l}-0.1363 * * * \\
(-45.8535)\end{array}$ & $\begin{array}{l}-0.0649 * * * \\
(-31.8451)\end{array}$ & $\begin{array}{r}-0.0467 * * * \\
(-30.3435)\end{array}$ & $\begin{array}{r}-0.0187 * * * \\
(-17.8252)\end{array}$ & $\begin{array}{c}-0.0369 * * * \\
(-24.3947)\end{array}$ & $\begin{array}{c}-0.0062 * * * \\
(-6.2263)\end{array}$ \\
\hline Size $_{i, t}$ & $\begin{array}{l}1.4965^{* * *} \\
(20.9064)\end{array}$ & $\begin{array}{c}0.0243 * * * \\
(18.7823)\end{array}$ & $\begin{array}{c}0.0152 * * * \\
(17.0306)\end{array}$ & $\begin{array}{l}0.0168 * * * \\
(25.1252)\end{array}$ & $\begin{array}{c}0.0127 * * * \\
(27.7690)\end{array}$ & $\begin{array}{c}0.0039 * * * \\
(6.0101)\end{array}$ & $\begin{array}{c}0.0026 * * * \\
(6.0581)\end{array}$ \\
\hline Constant & $\begin{array}{c}-13.0572 * * * \\
(-16.4082)\end{array}$ & $\begin{array}{l}-0.2023 * * * \\
(-12.8948)\end{array}$ & $\begin{array}{l}-0.1340 * * * \\
(-12.3925)\end{array}$ & $\begin{array}{l}-0.1244 * * * \\
(-11.2177)\end{array}$ & $\begin{array}{l}-0.0953 * * * \\
(-12.5079)\end{array}$ & $\begin{array}{c}-0.0063 \\
(-0.6412)\end{array}$ & $\begin{array}{l}-0.0070 \\
(-1.0881)\end{array}$ \\
\hline $\begin{array}{l}\text { Year } \\
\text { Industry }\end{array}$ & $\begin{array}{l}\text { Controlled } \\
\text { Controlled }\end{array}$ & $\begin{array}{l}\text { Controlled } \\
\text { Controlled }\end{array}$ & $\begin{array}{l}\text { Controlled } \\
\text { Controlled }\end{array}$ & $\begin{array}{l}\text { Controlled } \\
\text { Controlled }\end{array}$ & $\begin{array}{l}\text { Controlled } \\
\text { Controlled }\end{array}$ & $\begin{array}{l}\text { Controlled } \\
\text { Controlled }\end{array}$ & $\begin{array}{l}\text { Controlled } \\
\text { Controlled }\end{array}$ \\
\hline $\begin{array}{l}N \\
A d j-R^{2}\end{array}$ & 13362 & 13362 & 13362 & 10334 & 10334 & $\begin{array}{c}7811 \\
0.2784\end{array}$ & $\begin{array}{c}7811 \\
0.1262\end{array}$ \\
\hline $\begin{array}{l}\text { Chi }^{2} \\
\text { Pseudo } R^{2}\end{array}$ & $\begin{array}{c}5701.94 \\
0.3110 \\
\end{array}$ & 6961.06 & 7212.83 & 3700.38 & 2815.19 & & \\
\hline
\end{tabular}

Variable Definitions: See Table 1. In the reduced sample, we excluded companies that pay no dividends to shareholders over a continuous fiveyear period. In parentheses, we report $\mathrm{z}$ statistics for Logit model and $\mathrm{t}$ statistics for Tobit and OLS models. *, **, ***denote significance at the $10 \%, 5 \%$, and $1 \%$ levels, respectively.

The final four columns of Table 4 present the different models of dividend volatility (testing H2b). The coefficient on the interaction variable $\left(C L * G O_{i, t}\right)$, provides limited evidence (in the OLS models only) that dividend volatility responds more strongly to growth opportunities for cross-listed companies. These findings provide some weak evidence in support of $\mathrm{H} 2 \mathrm{~b}$, which suggests that the dividend payments of cross-listed companies may be more volatile than those of non-cross-listed companies when growth opportunities are higher.

\subsection{Limitations}

Our study is subject to a number of limitations. First, we examined the cross-listing status of Chinese companies, which tend to pay relatively high dividends (Lam et al., 2012). Cross-listing by companies from other 
emerging markets may not influence the free cash flow/dividend policy and growth opportunities/dividend policy relationships in the same way. Second, in addition to free cash flow and growth opportunities, cross-listings could influence the relationship between dividend policy and other factors such as the ownership structure and profitability. An extension of this paper could examine the moderating effect of cross-listings on the relationship between these variables and dividend policies. Finally, we did not attempt to measure share repurchases, which are viewed as a substitute for dividends by some researchers in the US market (Grullon \& Michaely, 2002). These limitations represent opportunities for future research.

\section{CONCLUSION AND IMPLICATIONS}

Resources generated by an organization through its profit-making activities can be allocated to two competing uses: to pay dividends or to make investments. A company's dividend policy should therefore respond to two main factors: the available resources, and the availability of projects that could benefit shareholders (Guttman et al., 2010). If the company retains resources in excess of their potential use for productive projects (i.e., the company does not pay enough dividends), the cash retained within the business may be misused by management. This misuse may arise from investing in projects (or paying more in managerial compensation) that will not increase shareholder wealth, resulting in overinvestment. The potential overinvestment of resources that could have been paid out as dividends is known as the "free-cash flow problem." However, if too much cash is paid out in dividends, some shareholder-wealth-increasing projects may not be pursued by the company due to scarcity of capital (i.e., underinvestment may occur). Cross-listed companies may be more shareholder-focused than their non-cross-listed counterparts, and thus their dividend policies may reflect a desire to avoid the free cash flow problem, while retaining sufficient resource to take advantage of growth opportunities. Therefore, cross-listed companies may structure their dividend policies to avoid both overinvestment and underinvestment.

Consistent with avoidance of the free cash flow problem and the increased shareholder focus of cross-listed companies, we find that the dividend payments of Chinese cross-listed companies respond more strongly to free cash flow than do the dividend payments of non-cross-listed companies. Cross-listed companies are likely to pay out more of their free cash flow than non-cross-listed companies, which can prevent managers from misusing the resources in ways that may not maximize shareholder wealth. We also find limited evidence of an interactive relationship between free cash flow, cross-listings, and dividend volatility, with the dividend payments of crosslisted companies being somewhat more volatile as they respond to changes in free cash flow.

We also find evidence that the dividend policies of cross-listed companies are more likely to result in retention of resources that can be put to productive use. Specifically, the dividends of cross-listed companies are smaller than those of non-cross-listed companies when the company has greater growth opportunities. The resources not paid out as dividends can then be used to fund projects which take advantage of the greater growth opportunities. Additionally, we find some limited evidence that the dividends of cross-listed companies are more volatile than those of non-cross-listed companies when growth opportunities are larger. These results may reflect changes over time in the growth opportunities to which the dividend payments respond.

Research suggests that companies that cross-list their shares may have better corporate governance (Charitou et al., 2007) and enhanced shareholder wealth (Doidge et al., 2004). The implications of our study are that cross-listed companies may be more likely to design dividend policies to encourage more appropriate investment of corporate resources. These cross-listed companies are less likely to overinvest or otherwise misuse free cash flow, as they pay more of the free cash flow out as dividends than non-cross-listed companies. Cross-listed companies are also less likely to underinvest in worthwhile projects, as cross-listed companies with stronger growth opportunities are more likely to retain corporate resources (rather than paid out as dividends) that can be used to fund these worthwhile projects.

\section{ACKNOWLEDGEMENTS}

We thank Justin Jin from McMaster University, Hao Wang from Huazhong University of Science and Technology, and Bei Yang from Xi'an Jiaotong University for their helpful comments. Financial support from New Century Excellent Talents Support Project of China's Ministry of Education (Approval number NCET-07-0309) and the National Natural Science Foundation of China (approval number 71172186) is acknowledged. 


\section{AUTHOR INFORMATION}

Zijian Cheng is a PhD candidate in accounting at Xi' an Jiaotong University, China. His research interests include international cross-listings, corporate governance, and dividend policy. E-mail: chengzijian.1987@foxmail.com

Charles P. Cullinan is a professor of accounting at Bryant University, USA. His research interests include audit markets, corporate governance, and dividend policies. His previous research has been published in a variety of journals such as Journal of Accounting and Public Policy, Auditing: A Journal of Practice and Theory, Critical Perspectives on Accounting, and Journal of Applied Business Research. He holds a PhD from the University of Kentucky. E-mail: cullinan@ bryant.edu (Corresponding author)

Junrui Zhang is a professor of accounting at Xi'an Jiaotong University, China. His research interest includes emerging capital markets, free cash flow manipulation, and R\&D. His previous studies have been published in journals such as Journal of International Accounting, Auditing \& Taxation, Asia-Pacific Journal of Accounting \& Economics, Advances in Accounting, and Journal of Applied Business Research. He received his PhD from Tianjin University of Finance Economics. E-mail: zhangjr@mail.xjtu.edu.cn

\section{REFERENCES}

1. Abor, J., \& Bopkin, G. A. (2010). Investment opportunities, corporate finance, and dividend payout policy: Evidence from emerging markets. Studies in Economics \& Finance, 27(3), 180-194.

2. Adjaoud, F., \& Ben-Amar, W. (2010). Corporate governance and dividend policy: Shareholders' protection or expropriation? Journal of Business Finance \& Accounting, 37, 648-667.

3. Allen, F., Qian, J., \& Qian, M. (2005). Law, finance, and economic growth in China. Journal of Financial Economics, 77(1), 57-116.

4. $\quad$ Baker, H. K., Chang, B., Dutta, S., \& Saadi, S. (2012). Why firms do not pay dividends: The Canadian experience. Journal of Business Finance \& Accounting, 39(9-10), 1330-1356.

5. Chae, J., Kim, S., \& Lee, E. J. (2009). How corporate governance affects payout policy under agency problems and external financing constraints. Journal of Banking \& Finance, 33, 2093-2101.

6. Charitou, A., Louca, C., \& Panayides, S. (2007). Cross-listing, bonding hypothesis and corporate governance. Journal of Business Finance \& Accounting, 34, 1281-1306.

7. Chen, D., Jian, M., \& Xu, M. (2009). Dividends for tunneling in a regulated economy: The case of China. Pacific-Basin Finance Journal, 17, 209-223.

8. Coffee, J. (1999). The future as history: The prospects for global convergence in corporate governance and its implications. Northwestern University Law Review, 93, 641-707.

9. Coffee, J. (2002). Racing towards the top?: The impact of cross-listings, and stock market competition on international corporate governance. Columbia Law Review, 102, 1757-1831.

10. Doidge, C., Karolyi, G. A., \& Stulz, R. M. (2004). Why are foreign firms listed in the US worth more? Journal of Financial Economics, 71, 205-238.

11. Fairchild, R. (2010). Dividend policy, signalling and free cash flow: an integrated approach. Managerial Finance, 36(5), 394-413.

12. Fama, E. F., \& French, K. R. (2001). Disappearng dividends: changing firm characteristics or lower propensity to pay? Journal of Financial Economics, 60, 3-43.

13. Frésard, L., \& Salva, C. (2010). The value of excess cash and corporate governance: Evidence from US cross-listing. Journal of Financial Economics, 98, 359-384.

14. Fuller, K., \& Blau, B. M. (2010). Signalling, free cash flow and "nonmonotonic" dividends. The Financial Review, 45, 21-56.

15. Griffin, P. A., Lout D. H., \& Sun, Y. (2010). Agency problems and audit fees: Further tests of the free cash flow hypothesis. Accounting \& Finance, 50, 321-350.

16. Grullon, G., \& Michaely, R. (2002). Dividends, share repurchases, and the subsitution hypothesis. The Journal of Finance, 52(4), 1649-1684.

17. Gugler, K. (2003). Corporate governance, dividend payout policy, and the interrelation between dividends, R\&D, and capital investment. Journal of Banking \& Finance, 27, 1297-1321. 
18. Gugler, K., \& Yurtoglu, B. B. (2003). Corporate governance and dividend pay-out policy in Germany. European Economic Review, 47(4), 731-758.

19. Guttman, I., Kadan, O., \& Kandel, E. (2010). Dividend stickiness and strategic pooling. The Review of Financial Studies, 23(12), 4455-4495.

20. Gwilym, O. A., Morgan, G., \& Thomas, S. (2000). Dividend stability, dividend yield and stock returns: UK evidence. Journal of Business Finance \& Accounting, 27, 261-281.

21. Jensen, M. C. (1986). Agency costs of free cash flow, corporate finance, and takeovers. The American Economic Review, 76, 323-329.

22. Jensen, M. C., \& Meckling, W. H. (1976). Theory of the firm: Managerial behavior, agency costs and ownership structure. Journal of Financial Economics, 3(4), 305-360.

23. Jiraporn, P., Kim, J. C., \& Kim, Y. S. (2011). Dividend payouts and corporate governance quality: An empirical investigation. The Financial Review, 46, 251-279.

24. Karpavicius, S., \& Yu. F. (2012). A test of the free cash flow hypothesis: The impact of increased institutional holdings on firm characteristics. (Social Science Research Network Working Paper No.1910976). Retrieved from http://papers.ssrn.com/sol3/papers.cfm?abstract_id=1910976

25. La Porta, R., Lopez-de-Silanes, F., Shleifer, A., \& Vishny, R. W. (2000). Agency problems and dividend policies around the world. The Journal of Finance, 55, 1-33.

26. Lam, K. C. K., Sami, H., \& Zhou. H. (2012). The role of cross-listing, foreign ownership and state ownership in dividend policy in an emerging market. China Journal of Accounting Research, 5, 199-219.

27. Leary, M. T., \& Michaely, R. (2011). Determinants of dividend smoothing: Empirical evidence. The Review of Financial Studies, 24(10), 3197-3249.

28. Lintner, J. (1956). Distribution of incomes of corporations among dividends, retained earnings, and taxes. The American Economic Review, 46, 97-113.

29. Mitton, T. (2004). Corporate governance and dividend policy in emerging markets. Emerging Markets Review, 5, 409-426.

30. Mukherjee, T., \& Baker, H. K. (2009). Dividends and dividend policy. New York: John Wiley \& Sons.

31. Noronha, G. M., Sen, N., \& Smith D. M. (1995). Determinants of the medium of payment in corporate acquisitions. Journal of Applied Business Research, 11(1), 15-23.

32. Reese, W. A., \& Weisbach, M. S. (2002). Protection of minority shareholder interests, cross-listings in the United States, and subsequent equity offerings. Journal of Financial Economics, 66, 65-104.

33. Richardson, S. (2006). Over-investment of free cash flow. Review of Accounting Studies, 11, $159-189$.

34. Stulz, R. M. (1999). Golbalization, corporate finance, and the cost of capital. Journal of Applied Corporate Finance, 12, 8-25.

35. Zhou, J., Zhang, T., \& Cui, S. (2011). Cross listing, corporate governance and corporate performance: Empirical evidence of Hong-Kong listed Chinese companies. Nankai Business Review International, 2(3), 275-288. 